\title{
Sentinel Lymph Node Biopsy In Breast Cancer: Validation Study And Comparison Of Lymphatic Mapping Techniques
}

\section{ABSTRACT}

Introduction: Sentinel lymph node biopsy is a standard staging procedure in patients with early breast cancer. Aim of the study is a validation procedure of sentinel lymph node biopsy (SLNB) in our institution and comparison between two mapping techniques - isotope mapping and methylene blue dye for lymphatic mapping.

Material and methods: The study comprised 75 women with breast cancer of clinical stage T1-2NOMO. We analyzed patients from June, 2010 to March, 2013. In 39 patients, (Group A) lymphatic mapping technique was performed by using the peritumoral injection of $37 \mathrm{MBq}$ activity isotope $(99 \mathrm{~m}$ Technetium NANOCIS), and in 36 patients (Group B) mapping technique was performed by using the periareolar injection of 2-4 ml blue dye (Methylene blue 1\%). Axillary dissection was performed in both groups after SLNB.

Results: Out of 75 patients, sentinel lymph node was identified in 68 (90.7\%). Identification rate was similar between the groups - 89.7\% (Group A), 91.7\% (Group B). Accuracy rate was $97 \%$ between the groups, that is, Group A 97.1\% and Group B 96.9\%. In relation to the Group A (90.6\%), sensitivity rate was slightly higher in the Group B - 91.6\%,. False negative rate of SLNB was higher in the Group A (9.1\%) in relation to the Group B (8.3\%). The average number of sentinel nodes detected in both groups was 1.2 .

Conclusion: The results of the study confirmed and validated both methods of lymphatic mapping techniques in SLNB. There were no significant statistical differences $(p>0.05)$ in accuracy, sensitivity and false negative rate between these two groups.

Keywords: breast cancer, sentinel lymph node biopsy, isotope, blue dye

\author{
Aleksandar Guzijan', \\ Božana Babić ${ }^{2}$ \\ Zdenka Gojković, \\ Radoslav Gajanin', \\ Jovan Ćulum ${ }^{3}$, \\ Davor Grahovac ${ }^{1}$
}

\author{
${ }^{1}$ Oncology Clinic, University hospital \\ Clinical center Banja Luka, \\ Banja Luka, Bosnia\&Herzegovina \\ ${ }^{2}$ Institute of pathology, University \\ hospital Clinical center Banja Luka, \\ Banja Luka, Bosnia\&Herzegovina \\ ${ }^{3}$ Faculty of Medicine, \\ University of Banja Luka, \\ Banja Luka, Bosnia\&Herzegovina
}

\section{Contact:}

Aleksandar Guzijan Oncology Clinic - Breast Center University hospital Clinical center Banja Luka

Dvanaest beba 1, Banja Luka Phone: 065/568-989, 051/342-435 E-mail: guzijan@hotmail.com

Submitted: August 23rd, 2014 Accepted: September 22th, 2014 


\section{Introduction}

On the basis of numerous clinical studies carried out over many years, the procedure of sentinel lymph node biopsy (SLNB) was taken as a valid procedure in diagnosing lymph node axillary metastasis in invasive breast cancer. ${ }^{1-3}$

In clinical manuals, the following methods of marking, that is, mapping of sentinel lymph node (SLN), are recommended: isotope mapping method, blue dye mapping method and a combined mapping method with blue dye and isotope. ${ }^{4,5}$ Before SLNB introduction, validation studies were conducted with the aim to determine predictive values of sentinel lymph node in relation to the status of other lymph nodes in the axilla, and, at the same time, to practice surgical teams in the procedure conducting. ${ }^{6-9}$ Practical importance of SLNB procedure can be seen in significant decreasing of postoperative comorbidity (lymphedema, parenthesis, pain, etc.) in relation to the patients who underwent axillary lymphadenectomy.

The study conducted in our institution had an aim to determine procedure validity and compare the methods of SLN blue dye mapping (methylene blue) and isotope (Technetium, 99Tc).

\section{Materials and methods}

The study was conducted in Clinical Center Banja Luka in the period from June, 2010 to March, 2013. It was approved by the Ethic Council of Clinical Center Banja Luka. 75 patients who fulfilled the criteria for participating in study were analyzed in this period. Sentinel biopsy procedure was first introduced to the patients and they gave a written consent to participate in the study. The patients fulfilled the following criteria to enter the study: female patients, 30-year-olds and more, histologically verified primary invasive breast cancer, unifocal tumor in a breast, clinical axillary area without dubious palpable lymph nodes, ultrasound check up without visualization of dubious infiltrated lymph nodes, clinic stage T1/2NoMo, that in the past, lymph node sentinel biopsy in axillary area was not performed, that axillary area was not treated by rays and/or operated, that a patient was not pregnant, and that a patient previously did not receive neoadjuvant chemotherapy.

The patients with histologically verified invasive breast cancer were separated in two groups: patients in which sentinel lymph node mapping was performed by isotope application (Group A), and in which sentinel lymph node mapping was performed by blue dye (Group B).

In Department of Nuclear Medicine of Clinical Center Banja Luka, radioisotope technetium-nano-sulphur colloid used in sentinel lymph node mapping procedure was obtained from pharmaceutics nano-sulphur colloid (Cis Bio international Paris, France) and technetium pertechnetate
(Tc99m). Preoperatively, in the case of a palpable tumor, radioisotope was applied subcutaneously peritumoral. In a case of a non-palpable tumor, radioisotope was applied periareolar, usually four puncture spots in the amount of $0.2 \mathrm{ml}$ per puncture spot in a dose of $0.25 \mathrm{mCi}(9.25 \mathrm{MBq})$, that is in total, $0.8 \mathrm{ml}$ in radioactivity dose $1 \mathrm{mCi}(37 \mathrm{MBq})$. The procedure was conducted 1 to 4 hours prior to an operation. Sentinel lymph node was intra-operatively detected by mobile gamma camera. Mobile gamma camera "Europrobe" (Lyon, France) was used for detection. While detecting, one or more sentinel lymph nodes were identified.

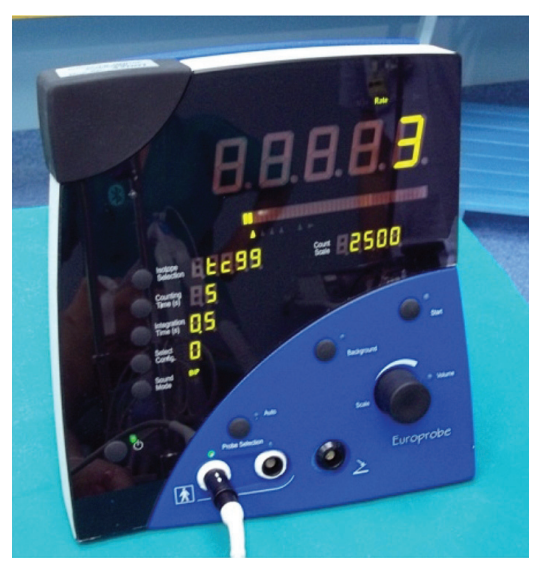

Figure 1. Mobile „gamma“ probe

All identified sentinel nodes were analyzed histopathologically intra-operatively ("ex tempore") on frozen sections, and afterwards, on permanent paraffin molds, depending on size and number of samples, by standard method of dyeing hematoxylin-eosine (HE).

During the operation, mobile gamma camera detected a place of greatest radiation, and after extirpation, radiation level of an extracted sentinel node was detected on a counter. As a proper parameter, a radiation detection 10 times bigger in relation to surrounding tissue was taken..,3 After performed sentinel lymph node biopsy, axillary lymphadenectomy was performed in all patients in the group. Total number of analyzed patients in Group A was 39 women.

In the other group (Group B), sentinel lymph node mapping was performed by method of dyeing with blue dye (Methylene blue 1\%), which is in our conditions available because of its economic acceptability. Methylene blue has smaller molecular weight in relation to patent blue and isosulphan blue. Immediately after giving anesthetic to the patient, blue dye (1\% Methylene blue) was applied subcutaneously periareolary to a breast quadrant where a tumor was localized in amount of 2 to $4 \mathrm{ml}$. After blue dye application, a gentle massage of a breast was done for 2-3 minutes in order to stimulate lymph drainage. In interval 
from 15 to 20 minutes from dye application, incision and exploration of axillary area and visual identification of sentinel lymph node were performed. After identification and extirpation of sentinel lymph node, axillary lymphadenectomy was performed in this group of patients as well. 36 women were analyzed in Group B.

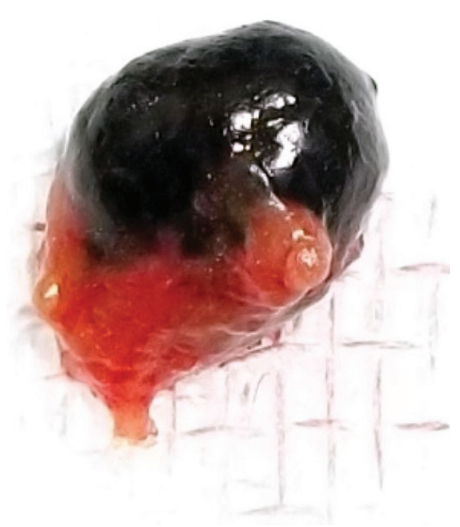

Figure 2. Sentinel lymph node mapped by blue dye

$\chi^{2}$ test, Fisher's exact test, Yates correction for continuity, Mann-Whitney's Test and Kolmogorov-Smirnov test were used in the analysis. Analytical statistical tool SPSS version 20 was used in statistical data processing.

\section{Results}

In statistical analysis of the patients, the following characteristics of examined groups were processed: age, tumor size, histological grade of a tumor, histological type of a tumor, lymph-vascular and perineural invasion of a tumor, immune-histochemical determined hormone status of a tumor and expression of HER2 gene. In the examined groups, model of an applied surgical treatment was analyzed.

Iin the attached statistical data analysis, except for the type of operation, there is no proved statistically significant difference between examined Groups A and B, according to their general characteristics.

In data related to sentinel biopsy, the following are processed: identification rate, accuracy rate, sentinel biopsy sensitivity rate, false negative results rate, average number of extracted sentinel lymph nodes and presence of micrometastasis in a sentinel lymph node and their correlation with other lymph nodes in dissection of axillary lymphatics.

In Group A, where mapping was performed by isotope, identification rate in the study was $89.7 \%$, while in group $\mathrm{B}$, where mapping was performed by blue dye, the rate was $91.7 \%$. In Group A, accuracy rate was $97.1 \%$ and in group B 96.9\%. Our results showed 90.9\% sensitivity rate in Group A and 91.6\% in Group B. False negative results rate in Group A was 9.1\% and in group B 8.3\%. Statistically significant difference between examined groups was not determined by using Fisher's test $(\mathrm{p}=1.000)$.

Table 1. Characteristics of examined patients and tumors

\begin{tabular}{|c|c|c|c|}
\hline & Group A & Group B & \\
\hline \multirow[t]{2}{*}{ Characteristics } & $\begin{array}{c}\text { (Radiotracer } \\
\text { 99mTc) }\end{array}$ & $\begin{array}{l}\text { (Methylene } \\
\text { blue) }\end{array}$ & $P$ \\
\hline & $n=39$ & $\mathrm{n}=36$ & \\
\hline Median age (years) & 58.6 & 59.9 & $0.983^{*}$ \\
\hline Median tumor size (mm) & 20.5 & 21.7 & $0.644^{*}$ \\
\hline \multicolumn{4}{|l|}{ Histological type } \\
\hline $\begin{array}{l}\text { Invasive ductal carcinoma } \\
\text { (NOS) }\end{array}$ & $26(66.7 \%)$ & 30 (83.3\%) & \\
\hline Invasive lobular carcinoma & 7 (17.9\%) & $1(2.8 \%)$ & \\
\hline Hystological grade of tumor & & & $0.068^{\star \star}$ \\
\hline Grade 1 & $9(23.1 \%)$ & $2(5.6 \%)$ & \\
\hline Grade 2 & $18(46.1 \%)$ & $24(66.7 \%)$ & \\
\hline Grade 3 & $12(30.8 \%)$ & $10(27.7 \%)$ & \\
\hline ER/PR positive & 35 (89.7\%) & $28(77.8 \%)$ & \\
\hline ER/PR negative & $4(10.3 \%)$ & $8(22.2 \%)$ & \\
\hline HER2 positive & $3(7.7 \%)$ & $9(25.0 \%)$ & \\
\hline HER2 negative & $36(92.3 \%)$ & 27 (75.0\%) & \\
\hline Type of surgery & & & $0.007^{\star *}$ \\
\hline $\begin{array}{l}\text { Modified radical } \\
\text { mastectomy }\end{array}$ & 7 (17.9\%) & $18(50.0 \%)$ & \\
\hline Breast conserving surgery & $24(61.5 \%)$ & $16(44.4 \%)$ & \\
\hline Skin sparing mastectomy & $8(20.6 \%)$ & $2(5.6 \%)$ & \\
\hline Side of tumor & & & $0.076^{\star *}$ \\
\hline Right breast & 17 (43.6\%) & 24 (66.7\%) & \\
\hline Left breast & 22 (56.4\%) & $12(33.3 \%)$ & \\
\hline \multicolumn{4}{|l|}{ Localization of tumor } \\
\hline Outer upper quadrant & $12(30.8 \%)$ & $10(27.8 \%)$ & \\
\hline $\begin{array}{l}\text { Junction of upper } \\
\text { quadrants }\end{array}$ & $9(23.1 \%)$ & $5(13.9 \%)$ & \\
\hline Upper inner quadrant & $16(41.0 \%)$ & $6(16.6 \%)$ & \\
\hline Others & 16 (41.0\%) & 15 (41.7\%) & \\
\hline
\end{tabular}

* - Mann Whitney test, ${ }^{* *}$ - c-square test 
Table 2. Sentinel biopsy results

\begin{tabular}{lcccc}
\hline & $\begin{array}{c}\text { Group A } \\
\text { (Radiotracer } \\
99 m T c)\end{array}$ & $\begin{array}{c}\text { Group B } \\
\text { (Methylene } \\
\text { blue 1\%) }\end{array}$ & P \\
& $\mathrm{n}=39$ & $\mathrm{n}=36$ & \\
\hline Identification rate & $\begin{array}{c}35 / 39 \\
(89.7 \%)\end{array}$ & $\begin{array}{c}33 / 36 \\
(91.7 \%)\end{array}$ & $1.000^{*}$ \\
\hline Accuracy rate & $34 / 35$ & $32 / 33$ & $1.000^{*}$ \\
\hline Sensitivity rate & $(97.1 \%)$ & $(96.9 \%)$ & \\
\hline Positive predictive value & $10 / 11$ & $11 / 12$ & $1.000^{*}$ \\
\hline Negative predictive value & $(90.9 \%)$ & $(91.6 \%)$ & \\
\hline False negative rate & $96.0 \%$ & $95.4 \%$ & \\
\hline Mean number of SLNs & $1 / 11(9.1 \%)$ & $1 / 12(8.3 \%)$ & \\
\hline
\end{tabular}

* - Fisher's exact test

\section{Discussion}

So far, many conducted comparative studies showed that a percentage of sentinel lymph node identification by usage of double method was bigger in relation to mapping using only blue dye or isotope. In comparison of sentinel lymph node mapping methods with blue dye and mapping with isotope, there was no statistically significant difference related to accuracy rate, sensitivity rate and false negative results rate of a sentinel node. ${ }^{10-12}$ Dilemma whether to use just one reagent or both in the sentinel biopsy procedure is still without consensus and for now, there are only recommendations.

Because of its acceptable price, methyleneblue is a dye which is available for all the health institutions. In the case of dye validity, methylene blue dye in a sentinel biopsy procedure, in relation to the other two (patent blue, isosulphane), previously conducted studies did not confirm superiority of patent blue and isosulphane in relation to methylene blue dye. The results of these studies showed that methylene blue dye is valid in sentinel biopsy procedure. There was no statistically significant difference in efficiency of sentinel biopsy procedure in relation to the method of dyeing with methylene and isosulphane or patent blue dye. ${ }^{13-15}$ Disadvantage of the studies dealing with methylene blue dye used in sentinel biopsy procedure was in a number of analyzed patients. Those were usually single institution studies involving a relatively small number of patients. Vital methylene blue dye related to patent and isosulphane dyes has certain advantages, such as lower price and low allergy potential, but it also has some disadvantages which reflect in lower resorption in lymph flow, in relation to the other two dyes. In our study, we applied methylene blue dye in 36 patients. In all examined patients who underwent sentinel biopsy procedure with methylene blue dye, we did not record any kind of allergic reactions. As for side effects, only mention temporary pigmentation of skin in the place where dye was injected and temporary urine discoloration is worth mentioning.

Nowadays, there is still no clear consensus and attitude about optimal spot for application of isotope and blue dye. There are two basic localizations for marker application. One technique is to apply isotope or blue dye in the tumor area, that is peritumoral, and the other one is based on applying the marker in the area of areolar complex, that is periareolar. The other dilemma concerns the depth of marker application; one option recommends superficial, subcutaneous application, and the other one recommends deeper, that is parenchyma marker application.

British study (The New Start) and French study (FRANSENODE) note that optimal spot for dye application is periareolar localization towards a breast quadrant of the tumor location, so as subcutaneous dye injection. ${ }^{716} \mathrm{We}$ practiced methylene blue dye application in periareolar area subcutaneously towards a breast quadrant where the tumor change was localized. This type of application is also more practical at non-palpable lesions.

In more extensive studies, identification rate was from $80 \%$ $-99 \%{ }^{1-3,6}$ On the basis of the results of the studies done so far, in most cases ,double method of sentinel node mapping has the biggest identification rate. Validity and success of SLNB procedure is valued on the basis of accuracy rate. SLNB accuracy rate in more extensive studies was from 95$99 \%{ }^{2,3,9}$ Sensitivity rate in study NSABP B-32 in mapping SLN by blue dye was $87.8 \%$, while isotope mapping was more successful with $92.2 \% .^{3}$ In some studies, sensitivity was greater in patients who underwent SLN mapping by blue dye. ${ }^{17}$ Many studies indicated bigger sensitivity rate in SLN mapping by double method. ${ }^{2,9}$ One of the first validation studies done at the area of former Yugoslavia showed blue dye sensitivity rate at $82 \%$ and double method at $95 \% .{ }^{18}$ SLN false negative results rate in the studies varied from $2-22 \% .^{19-21}$ In the studies involving greater number of examined patients, false negative results rate was from $6.7 \%, 8.2 \%$ to $11.4 \%{ }^{9,22,23}$ Results of validation study conducted in our institution pass all criteria set by most of training programs and recommendations of oncology associations dealing with introduction of SLNB procedure in standard use.

In present micro-metastasis in SLN, without any official confirmation in the form of clinical manuals, the attitude which is becoming more and more common is not doing the axillary lymphadenectomy. On the basis of obtained results of the study IBCSG 23-01 there was no statistically significant difference in five years period without disease (DFS, Disease free survival) between a group of patients who underwent lymphadenectomy and a group of patients who did not undergo lymphadenectomy after verified 
metastasis in SLN. ${ }^{24}$ In our study, micrometastatic deposits in SLN were verified in four patients, and observing the state of other lymph nodes in lymphadenectomy preparation, there were no verified metastatic deposits.

Recent studies (ACOSOG Zoo11 trial) have given the results which are still discussed by experts, and they are related to an attitude that axillary lymphadenectomy in early invasive breast cancer should not be done, not even if macrometastasis of breast cancer are histologically verified in sentinel lymph node. ${ }^{25}$ In such cases, axillary area would undergo radiotherapy. The results of the American study Zoo11 showed that there were no statistically significant difference between examined groups of patients regarding the overall survival (OS, Overall Survival) and a period without disease (DFS) in women who underwent axillary lymphadenectomy and those who underwent radiotherapy of axillary area after histologically verified macro-metastasis in SLN. ${ }^{25}$ A study of European Oncology Institute in Milan (SOUND trial) went even further, stating that in the case of early invasive breast cancer with clinically negative axillary area, nothing more than an observation should be done..$^{26} \mathrm{An}$ attitude of experts about this is not unanimous. ${ }^{27}$ German, Austrian and Swiss Senologic Society still withhold their attitude towards this subject. ${ }^{28}$ Their recommendation is to avoid lymphadenectomy in positive SLN only in groups of patient with a low risk for disease return and clinically and ultrasonographicly negative axillary area.

\section{Reference}

1. Veronesi U, Viale G, Path FRC, Paganelli G, Zurrida S, Luini A, et all. Sentinel lymph node biopsy in breast cancer: ten-year results of a randomized controlled study. Ann Surg 2010; 251(4): 595600.

2. Mansel RE, Fallowfield L, Kissin M, Goyal A, Newcombe RG, Dixon JM et al. Randomized multicenter trial of sentinel lymph node biopsy versus standard axillary treatment in operable breast cancer: the ALMANAC Trial. J Natl Cancer Inst 2006; 98: 599609

3. Krag DN, Anderson SJ, Julian TB, Brown AM, Harlow SP, Ashikaga $\mathrm{T}$, et al. Technical outcomes of sentinel lymph node resection and conventional axillary lymph node dissection in patients with clinically node negative breast cancer: results from the NSABP B-32 randomized phase III trial. Lancet Oncol 2007;8(10): 881888

4. Early and locally advanced breast cancer overview [Internet]. Manchester (UK): National institute for health and care excellence. 2012; [cited2013Aug3o]. Available from: http://pathways. nice.org.uk/pathways/early-and-locally-advanced-breast-cancer

5. Lyman GH, Giuliano AE, Somerfield MR, Benson AB, Bodurka DC, Burstein HJ, et al. American society of clinical oncology guideline recommendations for sentinel lymph node biopsy in early-stage breast cancer. J Clin Oncol 2005;23(30): 7703-7720

6. Krag D, Weaver D, Ashikaga T, Moffat F, Klimberg SV, Shriver C, et al. The sentinel node in breast cancer - a multicenter validation study. N Engl J Med 1998;339:941-946
7. Keshtgar M, Aresti N, MacNeil F. Establishing axillary sentinel lymph node biopsy (SLNB) for early breast cancer in the United Kingdom: A survey of the national training program. Eur J Surg Oncol 2010;36:393-398

8. Friis E, Galatius H, Garne JP. Organized nation-wide implementation of sentinel lymph node biopsy in Denmark. Acta Oncologica 2008;47: 556-560

9. Kuehn T, Vogl FD, Helms G, Pueckler SV, Schirrmeister H, Strueber R, et al. Sentinel node biopsy for axillary staging in breast cancer: results from a large prospective German multi-institutional trial. Eur J Surg Oncol 2004;30:252-259

10. Hung WK, Chan CM, Ying M, Chong SF, Mak KL, Yip AWC. Randomized clinical trial comparing blue dye with combined dye and isotope for sentinel lymph node biopsy in breast cancer. Br J Surg 2005;92:1494-1497

11. Varghese P, Mostafa A, Abdel-Rahman AT, Akberali S, Gattuso J, Canizales A et al. Methylene blue dye versus combined dye-radioactive tracer technique for sentinel lymph node biopsy localization in early breast cancer. Eur J Surg Oncol 2007;33:147-152

12. Derossis AM, Fey J, Yeung H, Yeh SD, Heerdt AS, Petrek J et al. A trend analysis of the relative value of blue dye and isotope localization in 2.000 consecutive cases of sentinel lymph node biopsy for breast cancer. J Am Coll Surg 2001;193:473-478

13. Eldrageely K, Vargas MP, Khalkhali I, Venegas R, Burla M, Gonzalez KD, et al. Sentinel lymph node mapping of breast cancer: a case control study of methylene blue tracer compared to isosulfan blue. The american surgeon 2004;70(10):872-875

14. Kavallaris A, Camara O, Runnebaum IB. Subareolar blue dye only injection sentinel lymph node biopsy could reduce the numbers of standard axillary lymph node dissection in environments without access to nuclear medicine. J Cancer Res Clin Oncol 2008;134:667-672

15. Chintamani, Tandon M, Mishra A, Agarwal U, Saxena S. Sentinel lymph node biopsy using dye alone method is reliable and accurate even after neo-adjuvant chemotherapy in locally advanced breast cancer - a prospective study. World J Surg Oncol 2011;9:19

16. Rodier JF, Velten M, Wilt M, Martel P, Ferron G, Vaini-Elies V, et al. Prospective multicentric randomized study comparing periareolar and peritumoral injection of radiotracer and blue dye for the detection of sentinel lymph node in breast sparing procedures: FRANSENODE trial. J Clin Oncol 2007;25:3664-3669

17. Meyer-Rochow GY, Martin RC, Harman RC. Sentinel node biopsy in breast cancer: validation study and comparison of blue dye alone with triple modality localization. ANZ J Surg 2003;73:815818

18. Radovanovic Z, Golubovic A, Plzak A, Stojiljkovic B, Radovanovic D. Blue dye versus combined blue dye - radioactive tracer technique in detection of sentinel lymph node in breast cancer. Eur $\mathrm{J}$ Surg Oncol 2004;30:913-917

19. Chua B, Olivotto IA, Donald JC, Hayashi AH, Doris PJ, Turner $\mathrm{LJ}$, et al. Outcomes of sentinel biopsy for breast cancer in British Columbia 1996-2001. Am J Surg 2003;185(2):118-126

20. Cox CE, Bass SS, McCann CR, Ku NN, Berman C, Durand K, et al. Lymphatic mapping and sentinel lymph node biopsy in patients with breast cancer. Annu Rev Med 2000;51:525-542 
21. Nano MT, Kollias J, Farchid G, Gill PG, Bochner M. Clinical impact of false-negative sentinel node biopsy in primary breast cancer. Br J Surg 2002;89(11):1430-1434

22. Harlow SP, Krag DN, Julian TB, Ashikaga T, Weaver DL, Feldman SA, et al. Prerandomization surgical training for the National Surgical Adjuvant Breast and Bowel Project (NSABP) B-32 trial: a randomized phase III clinical trial to compare sentinel node resection to conventional axillary dissection in clinically node negative breast cancer. Ann Surg 2005;241(1):48-54

23. Mansel R, MacNeill F, Horgan K, Goyal A, Britten A, Keshtgar M, et al. Results of a national training programme in sentinel lymph node biopsy for breast cancer. Br J Surg 2013;100(5):654-661

24. Galimberti V, Cole BF, Zurrida S, Viale G, Luini A, Veronesi P, et al. Axillary dissection versus no axillary dissection in patients with sentinel-node micrometastases (IBSCG 23-01): a phase 3 randomised controlled trial. Lancet Oncol 2013;14:297-305
25. Giuliano AE, McCall LM, Beitsch PD, Whitworth PW, Morrow M, Blumencranz PW, et al. ACOSOG Zoo11: A randomized trial of axillary node dissection in women with clinical T1-2 No Mo breast cancer who have a positive sentinel node. J Clin Oncol 2010; 28: 18

26. Gentilini O, Veronesi U. Abandoning sentinel lymph node biopsy in early breast cancer? A new trial in progress at the European Institute of Oncology of Milan (SOUND: Sentinel node vs Observation after axillary UltraSouND) The Breast 2012; 21(5): 678-681

27. Kumar A, Puri R, Gadgil PV, Jatoi I. Sentinel lymph node biopsy in primary breast cancer: window to management of the axilla. World J Surg 2012;36(7):1453-1459

28. The Consensus Panel. German, Austrian and Swiss consensus conference on the diagnosis and local treatment of the axilla in breast cancer. Eur J Cancer 2013;49(10):2277-2283

\section{Sentinel biopsija limfnog čvora kod karcinoma dojke: Validaciona studija i komparacija metoda obeležavanja sentinel čvora}

\section{SAŽETAK}

Cilj: Sentinel biopsija limfnog čvora je standard u tretmanu pacijenata oboljelih od ranog invazivnog karcinoma dojke. Cilj istraživanja je standardizacija procedure sentinel biopsije u našoj ustanovi i poređenje metode obilježavanja sentinel limfnog čvora između tehnike obilježavanja radiofarmakom i tehnike obilježavanja tkivnom bojom.

Materijal i metode: $U$ istraživanju je učestvovalo 75 žena oboljelih od karcinoma dojke sa kliničkim stadijumom T1/2NOMO. Ispitanice su analizirane u periodu od juna 2010. godine do marta 2013. godine. Kod 39 ispitanica (Grupa A), za obilježavanje sentinel čvora korišćen je radiofarmak Tehnecijum aplikovan peritumorski u aktivnosti od 37MBq. Kod 36 ispitanica (Grupa B), za obeležavanje je korišćena 1\% tkivna boja metilen plavo koja je aplikovana periareolarno u volumenu od 2-4ml. Disekcija aksilarnih limfatika sprovedena je kod svih pacijentkinja nakon procedure sentinel biopsije.

Rezultati: Od ukupno 75 analiziranih ispitanica, sentinel limfni čvor je identifikovan kod njih 68 (90,7\%). Stopa identifikacije bila je slična između poređenih grupa - u grupi A iznosila je 89,7\% , a u grupi B 91,7\%. Stopa preciznosti iznosila je 97\%, između poređenih grupa 97,1\% (Grupa A) i 96,9\% (Grupa B). Stopa senzitivnosti je bila nešto veća u grupi B (91,6\%) u odnosu na grupu A (90,9\%). Stopa lažno negativnih nalaza sentinel limfnog čvora bila je veća u grupi A $(9,1 \%)$ u odnosu na grupu B (8,3\%). Prosečan broj izvađenih sentinel čvorova iznosio je 1,2.

Zaključak: Rezultati istraživanja potvrdili su validnost obe metode obilježavanja kao i samu proceduru sentinel biopsije. Između poređenih grupa nije bilo značajne statističke razlike (p>0,05) u odnosu na stopu identifikacije, preciznosti, senzitivnosti i lažno negativnih nalaza.

Ključne riječi: karcinom dojke, sentinel biopsija, radiofarmak, tkivna boja 